\title{
Increased respiratory chemosensitivity induced by infusing almitrine intravenously in healthy man
}

\author{
NN STANLEY, JM GALLOWAY, B GORDON, N PAULY \\ Lister Hospital, Stevenage, Servier Research Institute, Fulmer, and Insitut de Recherches Internationales \\ Servier, Neuilly-sur-Seine, France
}

ABSTRACT The respiratory effects of intravenously infused almitrine were evaluated in healthy volunteers. In the dose range $0.25-1.0 \mathrm{mg} / \mathrm{kg} / \mathrm{hour}$ it caused large and dose-dependent increases in hypoxic chemosensitivity, which were longlasting and more persistent than the drug's retention in the plasma. Increases in sensitivity to hypercapnia were much less and were detected only when the plasma almitrine exceeded $200 \mathrm{ng} / \mathrm{ml}$. Small increases in resting ventilation and metabolic rate with a decrease in mixed venous carbon dioxide tension occurred only at the highest infusion rate. The findings accord with an action of almitrine in the peripheral chemoreceptors, which may be of therapeutic value in managing some cases of respiratory failure.

\begin{abstract}
Almitrine is a piperazine derivative which stimulates respiration in animals by an effect on the peripheral chemoreceptors but has no central activity. Thus its administration to anaesthetised dogs increases the neural discharge from their carotid body chemoreceptors, causing hyperpnoea only if the carotid sinus and vagus nerves are intact. Such stimulation evoked by intravenous injection of the drug is prolonged. ${ }^{1}$ The principal biological function of the peripheral chemoreceptors is to increase ventilation in hypoxia, ${ }^{2}$ whereas most of the ventilatory response to hypercapnia is mediated centrally. ${ }^{3}$ The present study was done to examine the respiratory effects and their duration when almitrine was infused intravenously in healthy man. Respiratory measurements were obtained not only during breathing of room air but also during the inhalation of either carbon-dioxide-enriched or hypoxic gas mixtures. In the first part of the investigation double-blind, placebo-controlled studies were performed with the drug given in a single dosage. Then the activity of the drug was examined on separate test days with three different doses.
\end{abstract}

\section{Methods}

The experimental subjects were 15 healthy medical students or doctors aged $22-42$ years. Fourteen

Address for reprint requests: Dr NN Stanley, Lister Hospital, Stevenage, Herts SG1 4AB. were male and one was female. Three subjects participated in both parts of the study. All were familiarised with the respiratory test procedures on a previous occasion and participated in the study after giving informed consent.

For placebo-controlled studies 12 subjects were given successive 45-minute infusions of almitrine $(0.5 \mathrm{mg} / \mathrm{kg} / \mathrm{h})$ and placebo intravenously. These were allocated randomly but equally under doubleblind conditions to separate treatment groups 1 and 2. In group 1 placebo preceded almitrine and in group 2 the order of infusion was reversed. Respiratory measurements were made beforehand (baseline) and near the end of each infusion period.

In the study of dose-response relationships almitrine was infused in six subjects at different rates $(0.25,0.5$ and $1.0 \mathrm{mg} / \mathrm{kg} / \mathrm{h})$ under single-blind conditions on three test days separated by intervals of at least one week. Again the infusions lasted 45 minutes and respiratory measurements were made before (baseline) and near the end of each infusion.

Respiratory measurements were performed during a 20-minute period, to determine in turn (a) ventilation $(\dot{\mathrm{V}})$, oxygen consumption $\left(\dot{\mathrm{Vo}}_{2}\right)$, carbon dioxide evolution $\left(\mathrm{VCO}_{2}\right)$ and respiratory exchange ratio (R); (b) mixed venous carbon dioxide tension $\left(\mathrm{P} \overline{\mathrm{v}} \mathrm{CO}_{2}\right) ;(c)$ forced expiratory volume in one second $\left(\mathrm{FEV}_{1}\right)$ and forced vital capacity (FVC); (d) ventilatory response to progressive hypercapnia in hyperoxia; and $(e)$ ventilatory response to progressive hypoxia in isocapnia. After a 10-minute settling 
down period with the subject wearing a nose clip and breathing ambient air through a mouthpiece connected to a unidirectional valve, expired air was collected in a Douglas bag for three minutes; $\dot{V}$ was measured by a dry gas meter and the oxygen and carbon dioxide concentrations of the expirate were analysed by a mass spectrometer for calculation of $\dot{\mathrm{V}} \mathrm{O}_{2}, \dot{\mathrm{V}} \mathrm{CO}_{2}$, and $\mathrm{R}$. $\mathrm{P} \overline{\mathrm{v}} \mathrm{CO}_{2}$ was estimated indirectly by a rebreathing technique. ${ }^{4} \mathrm{FEV}_{1}$ and FVC were measured during maximal forced expiration into a dry spirometer. The ventilatory responses were evaluated by modifications of established methods. ${ }^{5-7}$

Ventilatory responses were assessed with the subject rebreathing from a rubber bag sealed in a rigid box with a side-port connected to a pneumotachygraph for measurement of ventilation. Respired oxygen and carbon dioxide concentrations were analysed continously by the mass spectrometer.

For measurement of the response to hypercapnia the rubber bag was filled with about 51 of $6 \%$ carbon dioxide in oxygen, which was rebreathed for three to four minutes. Measurements during the first 30 seconds of rebreathing were discarded, after which ventilation was measured over the subsequent five-breath intervals and plotted against the corresponding alveolar carbon dioxide tension $\left(\mathrm{PaCO}_{2}\right)$ at the mid-point of each interval. The ventilation $\mathrm{PaCO}_{2}$ points are linearly related and the response to hypercapnia was quantified by the slope (S) of this relationship calculated by least-squares regression. The position of the response line was also calculated in terms of its intercept with the $\mathrm{PaCO}_{2}$ axis (parameter B). The coefficient of variation of repeated slope $\mathbf{S}$ measurements without prior almitrine administration was on average $12 \%$ in our subjects, comparable with the originally reported reproducibility of this measurement. ${ }^{5}$

For measurement of the response to hypoxia the rubber bag was refilled with approximately 51 of a gas mixture composed of $28 \%$ oxygen, $6 \%$ carbon dioxide, and balance nitrogen. During rebreathing the alveolar oxygen tension $\left(\mathrm{PaO}_{2}\right)$ fell progressively. To avoid differences in background carbon dioxide stimulation during the test periods the $\mathrm{PaCO}_{2}$ (after an initial rise) was held constant $( \pm 0.1 \mathrm{kPa})$ at the subject's baseline $\mathrm{PvCO}_{2}$ measured before administration of the drug. Isocapnia during rebreathing was achieved by sucking a proportion of the expired gas through a carbon dioxide scrubber with a variable-speed pump and then returning it to the rubber bag. Rebreathing was stopped when the $\mathrm{PaO}_{2}$ fell to about $5.3 \mathrm{kPa}(40 \mathrm{~mm} \mathrm{Hg})$ or if ventilation was stimulated to a level causing signs of distress. Measurements were started when the $\mathrm{PaO}_{2}$ had fallen to $14.7 \mathrm{kPa}(110 \mathrm{~mm} \mathrm{Hg})$. Thereafter ventilation was measured at five-breath intervals for comparison with the $\mathrm{PaO}_{2}$ existing 10 seconds before the mid-point of each interval, to allow for the circulation time between the alveoli and chemoreceptors. The plots of ventilation against $\mathrm{PaO}_{2}$ thus obtained have a rectangular hyperbolic relationship, which was converted to a linear function by subtracting $4.3 \mathrm{kPa}(32 \mathrm{~mm} \mathrm{Hg})$ from each $\mathrm{PaO}_{2}$ measurement and plotting ventilation in $1 / \mathrm{min}$ against $1 /\left(\mathrm{PaO}_{2}-4 \cdot 3\right)$, as suggested by others using different techniques. ${ }^{8}$ The slope (A) of this linear relationship was used to quantify the ventilatory response to hypoxia with values expressed numerically in what are necessarily arbitrary units owing to the lack of proportionality of ventilation with $\mathrm{PaO}_{2}$ or its reciprocal. We also calculated the intercept of the extrapolated linear relationship with the ventilation axis (Vo) when the $\mathrm{PaO}_{2}$ was infinite $\left(1 / \mathrm{PaO}_{2}-4 \cdot 3=0\right)$. The coefficient of variation of repeated slope $A$ measurements without prior almitrine administration was on average $14 \%$.

The pattern of breathing was assessed by calculating the tidal volume when ventilation reached 30 $\mathrm{l} / \mathrm{min}\left(\mathrm{Vt}_{30}\right)$ during hyperpnoea induced by both progressive hypercapnia and hypoxia.

For determination of plasma almitrine concentrations $10-\mathrm{ml}$ blood samples were collected at the end of each set of respiratory measurements. These were centrifuged and after separation of the plasma they were stored at $-20^{\circ} \mathrm{C}$ for subsequent analysis of almitrine concentration by gas chromatography, a modification of a previously described technique being used. ${ }^{9}$ The method has a coefficient of variation of $5 \%$ in repeated measurements over the range $50-500 \mathrm{ng} / \mathrm{ml}$. Specimens collected before infusion were used to exclude the presence of interfering substances.

Statistical analysis was performed by analysis of variance, paired $t$ tests, or regression analysis as appropriate.

\section{Results}

\section{PLACEBO-CONTROLLED STUDIES}

The table lists the mean ( \pm SEM) measurements during room air breathing, progressive hypercapnia, and progressive hypoxia in groups 1 and 2, which differed in the order in which the almitrine and placebo infusions were given. During the breathing of room air there were no consistent or significant changes during almitrine administration in $\dot{\mathrm{V}}, \dot{\mathrm{VO}}_{2}$, $\dot{\mathrm{V}} \mathrm{CO}_{2}, \mathrm{R}$, or $\mathrm{P} \dot{\mathrm{v}} \mathrm{CO}_{2} ; \mathrm{FEV}_{1}$ and $\mathrm{FVC}$ remained almost constant throughout.

Response to hypercapnia Almitrine infusion in both groups was accompanied 
Respiratory effects (expressed as means \pm SEM) of infusing placebo and almitrine ( $0.5 \mathrm{mg} / \mathrm{kg} / \mathrm{hour}$ ) successively in group 1 and in reverse order in group 2

\begin{tabular}{|c|c|c|c|c|c|c|c|c|c|}
\hline \multirow[b]{3}{*}{$\begin{array}{l}\text { Ventilation }(\mathrm{l} / \mathrm{min}) \\
\mathrm{O}_{2} \text { consumption }(\mathrm{mmol} / \mathrm{min}) \\
\mathrm{CO}_{2} \text { evolution }(\mathrm{mmol} / \mathrm{min}) \\
\text { Respiratory quotient } \\
\text { Mixed venous } \mathrm{CO}_{2} \text { tension }(\mathrm{kPa})\end{array}$} & \multicolumn{4}{|c|}{ Group $1(n=6)$} & \multicolumn{5}{|c|}{ Group $2(n=6)$} \\
\hline & \multirow{2}{*}{$\begin{array}{l}\text { Baseline } \\
\text { Room air bre } \\
8 \cdot 27 \pm 0 \cdot 30 \\
15 \cdot 3 \pm 1 \cdot 2 \\
11 \cdot 8 \pm 0.9 \\
0.78 \pm 0 \cdot 03 \\
6 \cdot 00 \pm 0.36\end{array}$} & \multirow{2}{*}{$\begin{array}{l}\text { Placebo } \\
\text { hing } \\
8.30 \pm 0.32 \\
15.1 \pm 1 \cdot 1 \\
10.9 \pm 0.7 \\
0.73 \pm 0.04 \\
5.89 \pm 0.39\end{array}$} & \multicolumn{2}{|c|}{ Almitrine } & \multirow{2}{*}{$\begin{array}{l}\text { Baseline } \\
\\
8 \cdot 22 \pm 0.71 \\
17.0 \pm 0.7 \\
12 \cdot 8 \pm 1 \cdot 0 \\
0 \cdot 74 \pm 0.04 \\
5.79 \pm 0.14\end{array}$} & \multicolumn{2}{|c|}{ Almitrine } & \multicolumn{2}{|c|}{ Placebo } \\
\hline & & & $\begin{array}{l}9 \cdot 00 \\
16 \cdot 4 \\
12 \cdot 4 \\
0 \cdot 76 \\
5 \cdot 93\end{array}$ & $\begin{array}{l} \pm 0.51 \\
\pm 1.0 \\
\pm 0.5 \\
\pm 0.04 \\
\pm 0.31\end{array}$ & & $\begin{array}{l}7.97 \\
16 \cdot 5 \\
12 \cdot 5 \\
0 \cdot 76 \\
5.77\end{array}$ & $\begin{array}{l} \pm 0.66 \\
\pm 1.0 \\
\pm 0.9 \\
\pm 0.02 \\
\pm 0.15\end{array}$ & $\begin{array}{l}8.55 \\
17.7 \\
12.9 \\
0.72 \\
5.80\end{array}$ & $\begin{array}{l} \pm 0.64 \\
\pm 0.8 \\
\pm 0.6 \\
\pm 0.02 \\
\pm 0.16\end{array}$ \\
\hline $\begin{array}{l}\text { Slope } S(1 / \mathrm{min} / \mathrm{kPa}) \\
\text { Parameter } \mathrm{B}(\mathrm{kPa}) \\
\text { Parameter } \mathrm{Vt}_{30}(\mathrm{l})\end{array}$ & $\begin{array}{l}\text { Progressive hy } \\
21 \cdot 0 \pm 2 \cdot 4 \\
5 \cdot 73 \pm 0 \cdot 19 \\
2 \cdot 06 \pm 0 \cdot 13\end{array}$ & $\begin{array}{l}20 \cdot 9 \pm 2 \cdot 3 \\
5 \cdot 65 \pm 0 \cdot 16 \\
2 \cdot 05 \pm 0 \cdot 17\end{array}$ & $\begin{array}{l}23 \cdot 6 \\
5 \cdot 71 \\
2 \cdot 08\end{array}$ & $\begin{array}{l} \pm 2 \cdot 9 \\
\pm 0 \cdot 22 \\
\pm 0.16\end{array}$ & $\begin{array}{l}16 \cdot 7 \pm 1 \cdot 8 \\
5 \cdot 61 \pm 0 \cdot 28 \\
2 \cdot 17 \pm 0 \cdot 31\end{array}$ & $\begin{array}{l}18 \cdot 0 \\
5 \cdot 62 \\
? \cdot 14\end{array}$ & $\begin{array}{l} \pm 2 \cdot 1 \\
\pm 6 \cdot 2 \\
\pm 0 \cdot 24\end{array}$ & $\begin{array}{l}20 \cdot 0 \\
5 \cdot 68 \\
2 \cdot 00\end{array}$ & $\begin{array}{l} \pm 2.7 \\
\pm 0.24 \\
\pm 0.23\end{array}$ \\
\hline $\begin{array}{l}\text { Slope A } \\
\text { Parameter } \dot{V}_{O}(\mathrm{~V} / \mathrm{min}) \\
\text { Parameter } \mathrm{Vt}_{30}(\mathrm{l})\end{array}$ & $\begin{array}{l}\text { Progressive } h \\
67.6 \pm 20 \cdot 4 \\
10.2 \pm 1.4 \\
1.97 \pm 0.13\end{array}$ & $\begin{array}{l}58 \cdot 9 \pm 12 \cdot 1 \\
12 \cdot 8 \pm 1 \cdot 3 \\
1 \cdot 96 \pm 0 \cdot 10\end{array}$ & $\begin{array}{l}135 \cdot 8 \\
12 \cdot 6 \\
1 \cdot 94\end{array}$ & $\begin{array}{l} \pm 25 \cdot 8^{*} \\
\pm 2 \cdot 6 \\
\pm 0 \cdot 07\end{array}$ & $\begin{array}{l}45 \cdot 5 \pm 11 \cdot 1 \\
12 \cdot 6 \pm 2 \cdot 4 \\
2 \cdot 06 \pm 0 \cdot 22\end{array}$ & $\begin{array}{l}110 \cdot 3 \\
11.9 \\
1.96\end{array}$ & $\begin{array}{l} \pm 20 \cdot 8^{*} \\
\pm 2 \cdot 0 \\
\pm 0 \cdot 19\end{array}$ & $\begin{array}{l}101 \cdot 6 \\
9 \cdot 3 \\
2 \cdot 02\end{array}$ & $\begin{array}{l} \pm 17 \cdot 3^{*} \\
\pm 2 \cdot 6 \\
\pm 0 \cdot 19\end{array}$ \\
\hline Plasma almitrine $(\mathrm{ng} / \mathrm{ml})$ & 0 & 0 & 172 & \pm 35 & 0 & 275 & \pm 49 & 71 & \pm 10 \\
\hline
\end{tabular}

*Significant increase above baseline value $(\mathrm{p}<0 \cdot 01)$.

Conversion: SI to traditional units-Blood gases: $1 \mathrm{mmol}=22.4 \mathrm{ml} ; 1 \mathrm{kPa}=7.5 \mathrm{~mm} \mathrm{Hg}$.

by only small increases in slope S (NS) and no change in parameter $B$ in comparison with their values in the baseline tests, or during the preceding placebo infusion in group 1. Plasma almitrine concentrations were very variable between subjects, however, with a range of $50-514 \mathrm{ng} / \mathrm{ml}$ despite identical rates of infusion. In the seven subjects whose plasma almitrine concentration exceeded $200 \mathrm{ng} / \mathrm{ml}$ slope $\mathrm{S}$ increased above baseline values on average by $17 \%$ during the drug's infusion $(p<0.05)$; such an increase in $\mathrm{S}$ occurred in six of these individuals, but there were no consistent changes in parameter B. The constancy of parameter B is in keeping with the lack of change in $\dot{\mathrm{V}}$ and $\mathrm{P}_{\mathrm{v}} \mathrm{CO}_{2}$ with the subjects breathing room air.

\section{Response to hypoxia}

In group 1 the measurements did not change significantly during the initial placebo infusion from the baseline values. Subsequently, with almitrine infusion slope $\mathbf{A}$ increased in every subject and on average was more than twice the values obtained before and during the placebo infusion $(p<0.01)$. Thus almitrine caused much greater stimulation of sensitivity to hypoxia than to hypercapnia. Vo was unchanged, which is consistent with a lack of ventilatory stimulation by almitrine without coexisting hypoxia. In group 2 there were also large increases in slope $A$ during almitrine infusion $(p<0.01)$. Although slope $\mathbf{A}$ had decreased when remeasured at the end of the 45-minute placebo infusion, it was still higher than baseline values in every subject $(p<$ 0.01 ), showing that the respiratory stimulation caused by almitrine was longlasting.
Correlation with plasma almitrine

Increases in slope $A$ above baseline evoked by almitrine plotted against drug concentration (based on the data of all 12 subjects) showed only a weak positive correlation $(\mathrm{r}=0.42$, NS). More striking was a contrast between the rates of decline in hypoxic chemosensitivity towards baseline levels and in plasma drug concentration when placebo was infused after almitrine in group 2. At the end of the placebo infusion the residual increment in slope $A$ above baseline was still $87 \%$ of the increase evoked by the preceding almitrine infusion. In contrast, the mean plasma almitrine concentration had declined to $26 \%$ of its value immediately before administration had ceased. The respiratory stimulation caused by almitrine was therefore more persistent than was its blood level $(p<0.01)$, and this was seen in all six subjects.

\section{Pattern of breathing}

There were no significant differences in $\mathrm{Vt}_{30} \stackrel{\mathrm{D}}{\mathrm{O}}$ whether hyperpnoea was induced by hypercapnia or by hypoxia during placebo or almitrine infusion. O This indicates that the drug did not alter the usual $N$ relationship between tidal volume, respiratory frequency, and minute ventilation.

\section{DOSE-RESPONSE RELATIONSHIPS}

At each of the three infusion rates $(0 \cdot 25,0 \cdot 5$, and $1.0 \mathrm{mg} / \mathrm{kg} / \mathrm{h}$ ) there were large and significant increases in slope $A(p<0.05)$. These averaged $79 \%, 169 \%$, and $306 \%$ and were roughly proportional to both the dosage and the plasma concentration of the drug. When the data from all 18 studies 


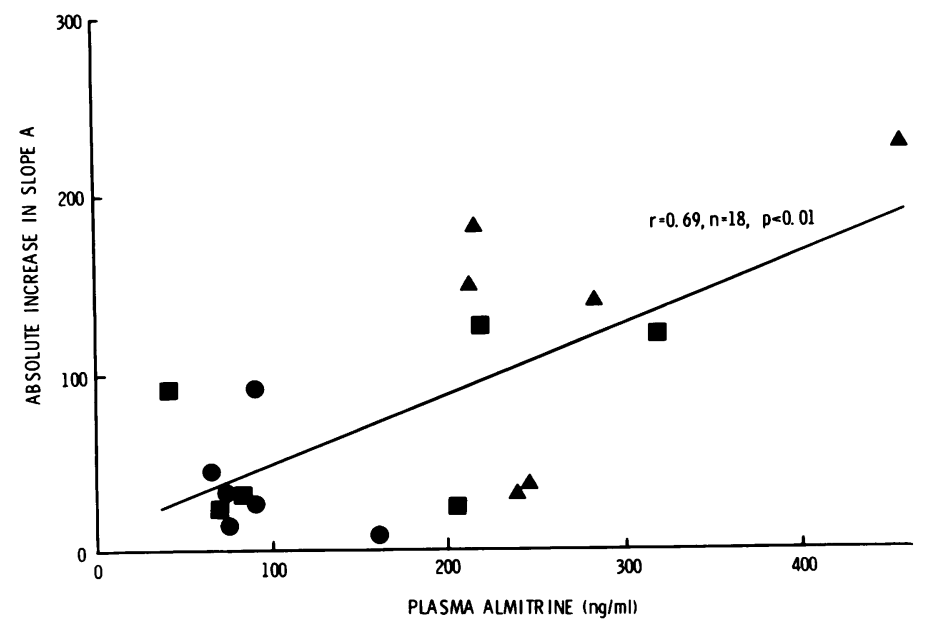

Absolute increases in slope A evoked by infusing almitrine at $0.25 \mathrm{mg} / \mathrm{kg} /$ $h(\Theta), 0.5 \mathrm{mg} / \mathrm{kg} / \mathrm{h}(\mathbf{\square})$, and $1.0 \mathrm{mg} / \mathrm{kg} / \mathrm{h}(\Delta)$ plotted against plasma concentrations (data from 18 experiments in six subjects).

at the three doses were pooled, a strong positive correlation $(r=0.69, p<0.01)$ was found between increases in slope $A$ and plasma concentration (fig); this reflected the dose dependency of the drug's effect on both variables since no significant correlations were observed at any single dosage.

Increases in slope $S$ were smaller than those in slope $A$ and were not significant when the data were analysed separately at each of the three infusion rates tested, but increases in S by an average of $21 \%$ occurred in eight of the nine studies where plasma almitrine exceeded $200 \mathrm{ng} / \mathrm{ml}(\mathrm{p}<0.05)$; this is in keeping with observations in the placebo-controlled studies. Giving almitrine at the two lower infusion rates had no appreciable effect on respiration during the breathing of room air, but while it was infused at the rate of $1.0 \mathrm{mg} / \mathrm{kg} / \mathrm{h}$ there were small increases in $\dot{\mathrm{V}}, \dot{\mathrm{V}}_{2}$, and $\dot{\mathrm{V}}_{2}$ (by $11 \%$ above baseline: $\mathrm{p}<$ 0.05 ) and a small fall in $\mathrm{P}_{\overline{\mathrm{C}}} \mathrm{CO}_{2}$ (from 6.1 to $5.9 \mathrm{kPa}$ : $\mathrm{p}<0.05$ ); correlations of these changes with plasma almitrine were not statistically significant. Spirometric measurements were unchanged irrespective of dosage or plasma concentration of the drug.

\section{Discussion}

Since the normal ventilatory response to hypoxia is abolished by chemodenervation in man, ${ }^{10}$ the observed increases in slope $A$ are consistent with a stimulatory action of almitrine on the peripheral chemoreceptors such as occurs in animals. ${ }^{1}$ That changes in $\dot{\mathrm{V}}$ and $\mathrm{P} \overline{\mathrm{v}} \mathrm{CO}_{2}$ were absent or minimal is not surprising because the subjects were normoxic when breathing room air. In this situation only a small proportion of the total respiratory drive arises from peripheral chemostimulation, and its minor effect on ventilation tends to be obscured in steadystate conditions. ${ }^{11}$ An increased contribution of peripheral chemostimulation to resting ventilatory drive during almitrine infusion, however, has been shown by others using transient oxygen administration. ${ }^{12}$ The finding that almitrine also augmented hypercapnic chemosensitivity was unexpected because the small contribution of peripheral chemoreceptors to the ventilatory response to hypercapnia becomes hard to detect in hyperoxia. ${ }^{3}{ }^{13}$ None the less, even during oxygen breathing carotid sinus nerve recordings in animals have shown some residual sensitivity to hypercapnia in carotid body receptors, ${ }^{14}$ which presumably can influence ventilatory responsiveness much more when the receptors are stimulated pharmacologically.

The variation between individuals in plasma concentrations of almitrine at each dosage has been observed by others, ${ }^{15}$ but not yet explained. It was far greater than the subjects' range of body weights and must reflect differences between subjects in pharmacokinetics of the drug. Variation in the degree of the drug's tissue binding within the chemoreceptors could explain the poor correlation at a given dosage between increases in hypoxic chemosensitivity and plasma concentration. There are two possible explanations for the fact that almitrine's biological effect on the response to hypoxia was more persistent than was its retention in the plasma. One is the presence of an active metabolite 
not measured by the chemical technique used for the almitrine assay. Alternatively, tissue binding of the drug within the peripheral chemoreceptors may not be rapidly reversible.

The clinical use of respiratory stimulants in the past has been criticised owing to serious side effects and practical difficulties linked with their administration. ${ }^{16-19}$ Therapeutic doses of analeptics may cause convulsions because of generalised cerebral stimulation and large increases in the metabolic rate occur that counter their ability to improve the blood gas state by means of increased ventilation, particularly in patients with limited ventilatory capacity. The usual need for intravenous administration coupled with an extremely brief duration of action pose the hazard of rebound hypoventilation after cessation or fluctuation in the infusion rate of the drug. Almitrine may circumvent these problems by having an extracerebral site of action that causes appreciable chemostimulation of ventilation at doses which have little or no effect on metabolic rate. No side effects were experienced by any of our subjects, and they were unable to distinguish between almitrine and placebo administration. Persistence of the drug's effect may improve the value of intravenous administration. Of additional importance is the fact that almitrine is an effective chemostimulant when given orally, ${ }^{20}$ which may provide a valuable new approach to the management of chronic ventilatory failure.

\section{References}

${ }^{1}$ Laubie M, Schmitt H. Long lasting hyperventilation induced by almitrine: evidence for a specific effect on carotid and thoracic chemoreceptors. Eur J Pharmacol 1980;61:125-36.

${ }^{2}$ Comroe JH Jr. The peripheral chemoreceptors. In: Fenn WO, Rahn H, eds. Handbook of physiology. Section 3: Respiration. Vol 1. Washington DC: American Physiological Society, 1964:557-83.

${ }^{3}$ Mitchell RA. Cerebrospinal fluid and the regulation of respiration. In: Caro CG, ed. Advances in respiratory physiology. London: Edward Arnold, 1966:1-47.

4 Campbell EJM, Howell JBL. Rebreathing method for measuring mixed venous $\mathrm{PCO}_{2} . \mathrm{Br}$ Med $\mathrm{J}$ 1962;ii:630-3.

5 Read DJC. A clinical method for assessing the ventilatory response to carbon dioxide. Australas Ann Med 1967;16:20-32.

${ }^{6}$ Godfrey S, Edwards RHT, Copland GM, Gross PL. Chemosensitivity in normal subjects, athletes, and patients with chronic airways obstruction. J Appl Physiol 1971;30:193-9.

7 Rebuck AS, Campbell EJM. A clinical method for assessing the ventilatory response to hypoxia. Am Rev Respir Dis 1974;109:345-50.

${ }^{8}$ Weil JV, Byrne-Quinn E, Sodal IE, et al. Hypoxic ventilatory drive in normal man. $J$ Clin Invest 1970;49:1061-72.

${ }^{9}$ Baune A, Bromet N, Courte S. Trace determination of almitrine in plasma by gas liquid chromotography using a nitrogen-phosphorus detector. J Chromatogr 1981;223:219-24.

${ }^{10}$ Holton P, Wood JB. The effects of bilateral removal of the carotid bodies and denervation of the carotid sinuses in two human subjects. J Physiol (Lond) 1965;198:365-78.

1 Dejours P. Control of respiration by arterial chemoreceptors. Ann N Y Acad Sci 1963;109:68295.

12 Flandrois R, Guérin JC. Action de l'almitrine sur le contrôle chémoréflexe de la ventilation chez l'homme sain et l'insuffisant respiratoire chronique. Rev Franc Mal Respir 1980;8:561-7.

${ }^{13}$ Wade JG, Larson CP Jr, Hickey RF, Ehrenfeld WK, Severinghaus JW. Effect of carotid endarterectomy on carotid chemoreceptor and baroceptor function in man. N Engl J Med 1970;282:823-9.

${ }^{14}$ Lahiri S, Delaney RG. Stimulus interaction in the responses of carotid body chemoreceptor single afferent fibers. Respir Physiol 1975;24:249-66.

${ }^{15}$ Bromet N, Aubert Y, Baune A, Courte S, Guillaudeux J. Etude de pharmacocinétique de l'almitrine. Rev Franç Mal Respir 1980;8:569-76.

${ }^{16}$ Cherniack RM, Young G. An evaluation of ethamivan as a respiratory stimulant in barbiturate intoxication, and alveolar hypoventilation in emphysema and obesity. Ann Intern Med 1964;60:631-40.

${ }^{17}$ Bickerman HA, Chusid EL. The case against respiratory stimulants. Chest 1970;58:53-6.

18 Winnie AP. Chemical respirogenesis: a comparative study. Acta Anaesthesiol Scand 1973;51, suppl:1-32.

${ }^{19}$ Hunt CE, Inwood RJ, Shannon DC. Respiratory and nonrespiratory effects of doxapram in congenital central hypoventilation syndrome. Am Rev Respir Dis 1979;119:263-9.

${ }^{20}$ Stanley NN. Almitrine a promising new drug for sleep hypoxia. Lancet 1981 ;ii:921. 